J. Pestic. Sci., 30(3), 192-198 (2005)

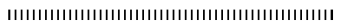

Original Article

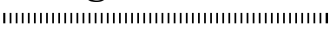

\title{
Synthesis and Anti-Juvenile Hormone Activity of Ethyl 4-[2-(6-Methyl-3-pyridyloxy)alkyloxy]benzoates
}

\author{
Norihiro FujtTa, Kenjiro Furuta, Hiromitsu Shirahashi, Soonsung Hong, \\ Takahiro SHIOTSUKI ${ }^{\dagger}$ and Eiichi KuwANO* \\ Laboratory of Pesticide Chemistry, Department of Applied Genetics and Pest Management, \\ Faculty of Agriculture, Kyushu University, Fukuoka 812-8581, Japan \\ ${ }^{\dagger}$ Laboratory of Insect Growth Regulation, Developmental Biology Department, \\ National Institute of Agrobiological Sciences, Tsukuba, Ibaraki 305-8634, Japan
}

(Received January 27, 2005; Accepted March 14, 2005)

\begin{abstract}
A series of ethyl 4-[2-(6-methyl-3-pyridyloxy)alkyloxy]benzoates was prepared and tested for activity to induce precocious metamorphosis in larvae of the silkworm, Bombyx mori. Of the compounds tested, ethyl 4-[4-methyl2-(6-methyl-3-pyridyloxy)pentyloxy]benzoate (5) was the most effective when applied to 24 hr-old 3rd instar larvae. There was no significant difference in precocious metamorphosis-inducing activity between $\mathbf{5 R}(+)$ - and $\mathbf{5 S}(-)$-enatiomers. The activity of compound $\mathbf{5}$ could be fully counteracted by methoprene, a juvenile hormone (JH) agonist, but not by the dietary administration of 20-hydroxyecdysone. When 3rd instar larvae were treated with compound $\mathbf{5}$, hemolymph $\mathrm{JH}$ esterase activity, which is indispensable for the initiation of pupation in normal last instar larvae, was induced during the 4 th instar. (C) Pesticide Science Society of Japan
\end{abstract}

Keywords: anti-juvenile hormone, precocious metamorphosis, silkworm, juvenile hormone esterase.

\section{INTRODUCTION}

Several compounds have been reported to possess activity which interferes with the actions of juvenile hormone $(\mathrm{JH})$ in insects. ${ }^{1)}$ These anti-JH agents include precocenes, fluoromevalonate (FMev), dichloroallyl hexanoate, ethyl 4-[2-( $t$ butylcarbonyloxy)butoxy]benzoate (ETB), 1,5-disubstituted imidazoles and brevioxime. ${ }^{2)}$ Although anti-JH agents are potential insect growth regulators as well as an effective tool in studies of insect physiology, none of the compounds has been developed for practical use in pest control as yet.

ETB has been found to show JH-like activity as well as anti-JH activity in Manduca sexta ${ }^{3)}$ and Bombyx mori, ${ }^{4)}$ depending on the dose applied; low doses induced precocious metamorphosis as a clear sign of JH-deficiency, but at higher doses, the anti-JH activity disappeared and instead, JH-like activity was observed. Edwards et al. have reported that the application of ETB results in a reduction of endogenous $\mathrm{JH}$ titers in $M$. sexta larvae. ${ }^{5)}$ In addition, Riddiford et al. have shown that ETB acts as a partial JH antagonist at the target tissue of the larval epidermis. ${ }^{6}$ By modifying the structure of

\footnotetext{
* To whom correspondence should be addressed.

E-mail: ekuwano@agr.kyushu-u.ac.jp

(C) Pesticide Science Society of Japan
}

ETB, we have recently found that ethyl 4-[2-(6-methyl-3pyridyloxy)butyloxy]benzoate (1) induced precocious metamorphosis in larvae of $B$. mori even at high doses. ${ }^{7)}$ From a preliminary study of the structure-activity relationship, the 4ethoxycarbonyl group on the benzene ring, a partial skeleton of ETB, was apparently essential for activity. We further synthesized analogs in which the ethyl side chain of 1 was modified, and evaluated their activity to induce precocious metamorphosis. In this paper we describe details of the preparation and structure-activity relationships of a number of ethyl 4-[2(6-methyl-3-pyridyloxy)alkyloxy]benzoates and the correlation between JH esterase (JHE) and precocious metamorphosis induced by the best member of the series.

\section{MATERIALS AND METHODS}

\section{Instrumental Analysis}

The ${ }^{1} \mathrm{H}-\mathrm{NMR}$ spectra were determined with a JEOL EX-400 $(400 \mathrm{MHz})$ spectrometer. Optical rotation values were measured with a Union Giken PM-101 polarimeter. HPLC analysis was carried out with a Shimadzu LC-10A equipped with a Shimadzu UV-VIS diode array. All melting points (mp) are uncorrected.

\section{Chemicals}

Compound 1 and ETB were prepared according to procedures 
reported previously. ${ }^{7)}$ Methyl (S)-2-hydroxy-4-methylpentanoate and its enantiomer $(R)$ were prepared from L-leucine and D-leucine, respectively, according to the method described by Valls et $a l^{8)}$ The preparation of a series of ethyl 4-[2-(6methyl-3-pyridyloxy)alkyloxy]benzoates (2-9) and optically active $\mathbf{5} \mathbf{R}$ is outlined in Fig. 1(A) and (B), respectively.

2.1. Ethyl 4-methyl-2-(6-methyl-3-pyridyloxy)pentanoate (I).

A mixture of $2.2 \mathrm{~g}$ of ethyl 2-bromoisobutyrate, $1.3 \mathrm{~g}$ of 5-hydroxy-2-methylpyridine and $2.7 \mathrm{~g}$ of potassium carbonate in $50 \mathrm{ml}$ of dimethylformamide (DMF) was stirred for $12 \mathrm{hr}$ at room temperature. The mixture was poured into $50 \mathrm{ml}$ of water and the product was extracted with $100 \mathrm{ml}$ of ethyl acetate. The ethyl acetate solution was washed with brine, dried over $\mathrm{Na}_{2} \mathrm{SO}_{4}$, and concentrated. The residue was purified by column chromatography on silica gel eluting with hexaneethyl acetate $(1: 1)$ to afford $1.95 \mathrm{~g}(78 \%)$ of compound (I). ${ }^{1} \mathrm{H}-\mathrm{NMR} \delta\left(\mathrm{CDCl}_{3}\right): 0.94\left(3 \mathrm{H}, \mathrm{d}, J=6.3 \mathrm{~Hz}, \mathrm{CH}_{3}\right), 1.00(3 \mathrm{H}$, d, $\left.J=6.3 \mathrm{~Hz}, \mathrm{CH}_{3}\right), 1.25\left(3 \mathrm{H}, \mathrm{t}, J=7.2 \mathrm{~Hz}, \mathrm{CH}_{3}\right), 1.67-1.75$ (1H, m, CH), 1.89-1.97 (2H, m, $\left.\mathrm{CH}_{2}\right), 2.47\left(3 \mathrm{H}, \mathrm{s}, \mathrm{CH}_{3}\right)$, $4.20\left(2 \mathrm{H}, \mathrm{q}, J=7.2 \mathrm{~Hz}, \mathrm{CH}_{2}\right), 4.59-4.62(1 \mathrm{H}, \mathrm{m}, \mathrm{CH}), 7.03-$ 7.10 (2H, m, pyridyl), $8.16(1 \mathrm{H}, \mathrm{d}, J=2.4 \mathrm{~Hz}$, pyridyl).

2.2. 4-Methyl-2-(6-methyl-3-pyridyloxy)pentyl p-toluenesulfonate (II).

A mixture of $1.9 \mathrm{~g}$ of (I) and $1.6 \mathrm{~g}$ of lithium aluminum hydride in $40 \mathrm{ml}$ of tetrahydrofuran (THF) was stirred for $1 \mathrm{hr}$ at room temperature. The reaction was quenched with saturated $\mathrm{NH}_{4} \mathrm{Cl}$ solution. After removal of the solvent under reduced pressure, the product was extracted with tert-butyl methyl ether. The ether solution was washed with brine and dried over $\mathrm{Na}_{2} \mathrm{SO}_{4}$. Concentration of the organic layer gave $0.7 \mathrm{~g}$ of crude 4-methyl-2-(6-methyl-3-pyridyloxy)pentanol. To a solution of this alcohol in $10 \mathrm{ml}$ of THF was added $0.4 \mathrm{~g}$ of triethylamine and $0.8 \mathrm{~g}$ of $p$-toluenesulfonyl chloride, and the mixture was stirred for $6 \mathrm{hr}$ at room temperature. After removal of the solvent under reduced pressure, the product was extracted with tert-butyl methyl ether. The ether solution was washed with brine, dried over $\mathrm{Na}_{2} \mathrm{SO}_{4}$, and concentrated. The residue was purified by column chromatography on silica gel eluting with hexane-ethyl acetate $(1: 1)$ to afford $0.6 \mathrm{~g}(50 \%)$ of compound (II). ${ }^{1} \mathrm{H}-\mathrm{NMR} \delta\left(\mathrm{CDCl}_{3}\right): 0.86(3 \mathrm{H}, \mathrm{d}, J=6.8$ $\left.\mathrm{Hz}, \mathrm{CH}_{3}\right), 0.92\left(3 \mathrm{H}, \mathrm{d}, J=6.8 \mathrm{~Hz}, \mathrm{CH}_{3}\right), 1.27-1.38(1 \mathrm{H}, \mathrm{m}$, $\mathrm{CH}), 1.59-1.64\left(2 \mathrm{H}, \mathrm{m}, \mathrm{CH}_{2}\right), 2.43\left(3 \mathrm{H}, \mathrm{s}, \mathrm{CH}_{3}\right), 2.47(3 \mathrm{H}, \mathrm{s}$, $\left.\mathrm{CH}_{3}\right), 4.07-4.15\left(2 \mathrm{H}, \mathrm{m}, \mathrm{CH}_{2}\right), 4.40-4.45(1 \mathrm{H}, \mathrm{m}, \mathrm{CH})$, 6.99-7.06 (2H, m, pyridyl), 7.29 (2H, d, $J=8.1 \mathrm{~Hz}$, phenyl), $7.71(2 \mathrm{H}, \mathrm{d}, J=8.1 \mathrm{~Hz}$, phenyl), $8.05(1 \mathrm{H}, \mathrm{d}, J=2.4 \mathrm{~Hz}$, pyridyl).

\subsection{Ethyl 4-[4-methyl-2-(6-methyl-3-pyridyloxy)penty-} loxy]benzoate (5).

A mixture of $0.33 \mathrm{~g}$ of ethyl 4-hydroxybenzoate, $0.60 \mathrm{~g}$ of (II), and $0.27 \mathrm{~g}$ of potassium carbonate in $30 \mathrm{ml}$ of DMF was heated at $90-100^{\circ} \mathrm{C}$ for $6 \mathrm{hr}$. To the mixture was added $20 \mathrm{ml}$ of water and the product was extracted with tert-butyl methyl ether. The ether solution was washed with $2 \mathrm{M} \mathrm{NaOH}$ solution and brine, dried over $\mathrm{Na}_{2} \mathrm{SO}_{4}$, and concentrated. The residue was purified by column chromatography on silica gel eluting with hexane-ethyl acetate $(2: 1)$ to afford $0.58 \mathrm{~g}(99 \%)$ of 5 as a white solid, mp $48-50^{\circ} \mathrm{C} .{ }^{1} \mathrm{H}-\mathrm{NMR} \delta\left(\mathrm{CDCl}_{3}\right): 0.93(3 \mathrm{H}, \mathrm{d}$, $\left.J=6.8 \mathrm{~Hz}, \mathrm{CH}_{3}\right), 0.99\left(3 \mathrm{H}, \mathrm{d}, J=6.8 \mathrm{~Hz}, \mathrm{CH}_{3}\right), 1,37(3 \mathrm{H}, \mathrm{t}$, $\left.J=6.8 \mathrm{~Hz}, \mathrm{CH}_{3}\right), 1.53-1.65(1 \mathrm{H}, \mathrm{m}, \mathrm{CH}), 1.71-1.88(2 \mathrm{H}, \mathrm{m}$, $\left.\mathrm{CH}_{2}\right), 2.50\left(3 \mathrm{H}, \mathrm{s}, \mathrm{CH}_{3}\right), 4.09-4.17\left(2 \mathrm{H}, \mathrm{m}, \mathrm{CH}_{2}\right), 4.34(2 \mathrm{H}$, q, $\left.J=6.8 \mathrm{~Hz}, \mathrm{CH}_{2}\right), 4.63-4.67(1 \mathrm{H}, \mathrm{m}, \mathrm{CH}), 6.88(2 \mathrm{H}, \mathrm{d}$, $J=8.3 \mathrm{~Hz}$, phenyl), $7.06(1 \mathrm{H}, \mathrm{d}, J=8.3 \mathrm{~Hz}$, pyridyl), $7.21(1 \mathrm{H}$, dd, $J=2.4,8.3 \mathrm{~Hz}$, pyridyl), 7.97 ( $2 \mathrm{H}, \mathrm{d}, J=8.3 \mathrm{~Hz}$, phenyl), $8.28(1 \mathrm{H}, \mathrm{d}, J=2.4 \mathrm{~Hz}$, pyridyl).

Compounds 2-4 and 6-9 were prepared in the same manner as compound 5 but with use of the corresponding ethyl 2bromoalkanoate instead of ethyl 2-bromoisobutyrate. The yields were calculated based on the starting 5-hydroxy-2methylpyridine.

Ethyl 4-[2-(6-methyl-3-pyridyloxy)pentyloxy]benzoate (2). Yield 17\%; oil; ${ }^{1} \mathrm{H}-\mathrm{NMR} \delta\left(\mathrm{CDCl}_{3}\right): 0.97(3 \mathrm{H}, \mathrm{t}, J=7.3 \mathrm{~Hz}$, $\left.\mathrm{CH}_{3}\right), 1.38\left(3 \mathrm{H}, \mathrm{t}, J=7.3 \mathrm{~Hz}, \mathrm{CH}_{3}\right), 1.43-1.60\left(2 \mathrm{H}, \mathrm{m}, \mathrm{CH}_{2}\right)$, 1.69-1.84 (2H, m, $\left.\mathrm{CH}_{2}\right), 2.50\left(3 \mathrm{H}, \mathrm{s}, \mathrm{CH}_{3}\right), 4.09-4.19(2 \mathrm{H}$, $\left.\mathrm{m}, \mathrm{CH}_{2}\right), 4.34\left(2 \mathrm{H}, \mathrm{q}, J=7.3 \mathrm{~Hz}, \mathrm{CH}_{2}\right), 4.54-4.60(1 \mathrm{H}, \mathrm{m}$, $\mathrm{CH}), 6.89(2 \mathrm{H}, \mathrm{d}, J=8.5 \mathrm{~Hz}$, phenyl), $7.06(1 \mathrm{H}, \mathrm{d}, J=8.8 \mathrm{~Hz}$, pyridyl), 7.15-7.22 (1H, m, pyridyl), $7.97(2 \mathrm{H}, \mathrm{d}, J=8.5 \mathrm{~Hz}$, phenyl), 8.26 (1H, d, $J=2.4 \mathrm{~Hz}$, pyridyl).

Ethyl 4-[3-methyl-2-(6-methyl-3-pyridyloxy)butyloxy]benzoate (3). Yield 5\%; oil; ${ }^{1} \mathrm{H}-\mathrm{NMR} \delta\left(\mathrm{CDCl}_{3}\right): 1.06(3 \mathrm{H}, \mathrm{d}$, $\left.J=7.3 \mathrm{~Hz}, \mathrm{CH}_{3}\right), 1.09\left(3 \mathrm{H}, \mathrm{d}, J=7.3 \mathrm{~Hz}, \mathrm{CH}_{3}\right), 1.22-1.28(1 \mathrm{H}$, $\mathrm{m}, \mathrm{CH}), 1.38\left(3 \mathrm{H}, \mathrm{t}, J=6.9 \mathrm{~Hz}, \mathrm{CH}_{3}\right), 2.49\left(3 \mathrm{H}, \mathrm{s}, \mathrm{CH}_{3}\right)$, 4.15-4.22 (2H, m, $\left.\mathrm{CH}_{2}\right), 4.34\left(2 \mathrm{H}, \mathrm{q}, J=6.9 \mathrm{~Hz}, \mathrm{CH}_{2}\right)$, 4.30-4.38 (1H, m, CH), $6.88(2 \mathrm{H}, \mathrm{d}, J=8.8 \mathrm{~Hz}$, phenyl), 7.05 (1H, d, $J=8.3 \mathrm{~Hz}$, pyridyl), $7.22(1 \mathrm{H}, \mathrm{dd}, J=2.4,8.3 \mathrm{~Hz}$, pyridyl), 7.97 (2H, d, $J=8.8 \mathrm{~Hz}$, phenyl), $8.27(1 \mathrm{H}, \mathrm{d}$, $J=2.4 \mathrm{~Hz}$, pyridyl).

Ethyl 4-[2-(6-methyl-3-pyridyloxy)hexyloxy]benzoate (4). Yield 18\%; oil; ${ }^{1} \mathrm{H}-\mathrm{NMR} \delta\left(\mathrm{CDCl}_{3}\right): 0.92(3 \mathrm{H}, \mathrm{t}, J=7.3 \mathrm{~Hz}$, $\left.\mathrm{CH}_{3}\right), 1.25-1.45\left(4 \mathrm{H}, \mathrm{m}, 2 \mathrm{CH}_{2}\right), 1.38\left(3 \mathrm{H}, \mathrm{t}, J=7.3 \mathrm{~Hz}, \mathrm{CH}_{3}\right)$, 1.76-1.83 (2H, m, $\left.\mathrm{CH}_{2}\right), 2.50\left(3 \mathrm{H}, \mathrm{s}, \mathrm{CH}_{3}\right), 4.10-4.19(2 \mathrm{H}$, $\left.\mathrm{m}, \mathrm{CH}_{2}\right), 4.34\left(2 \mathrm{H}, \mathrm{q}, J=7.3 \mathrm{~Hz}, \mathrm{CH}_{2}\right), 4.54-4.58(1 \mathrm{H}, \mathrm{m}$, $\mathrm{CH}), 6.89$ (2H, d, $J=8.8 \mathrm{~Hz}$, phenyl), $7.06(1 \mathrm{H}, \mathrm{d}, J=8.7 \mathrm{~Hz}$, pyridyl), $7.21(1 \mathrm{H}, \mathrm{dd}, J=2.4,8.7 \mathrm{~Hz}$, pyridyl), $7.98(2 \mathrm{H}, \mathrm{d}$, $J=8.8 \mathrm{~Hz}$, phenyl), $8.26(1 \mathrm{H}, \mathrm{d}, J=2.4 \mathrm{~Hz}$, pyridyl).

Ethyl 4-[3,3-dimethyl-2-(6-methyl-3-pyridyloxy)butyloxy]benzoate (6). Yield 24\%; mp 54-56 ${ }^{\circ} \mathrm{C} ;{ }^{1} \mathrm{H}-\mathrm{NMR} \delta\left(\mathrm{CDCl}_{3}\right)$ : $1.08\left(9 \mathrm{H}, \mathrm{s}, 3 \mathrm{CH}_{3}\right), 1.38\left(3 \mathrm{H}, \mathrm{t}, J=6.8 \mathrm{~Hz}, \mathrm{CH}_{3}\right), 2.49(3 \mathrm{H}, \mathrm{s}$, $\left.\mathrm{CH}_{3}\right), 4.14-4.19$ (1H, m, CH), 4.26-4.37 (4H, m, 2CH $), 6.84$ (2H, d, $J=8.8 \mathrm{~Hz}$, phenyl), $7.04(1 \mathrm{H}, \mathrm{d}, J=8.8 \mathrm{~Hz}$, pyridyl), 7.21-7.28 (1H, m, pyridyl), $7.96(2 \mathrm{H}, \mathrm{d}, J=8.8 \mathrm{~Hz}$, phenyl), $8.31(1 \mathrm{H}, \mathrm{d}, J=2.9 \mathrm{~Hz}$, pyridyl).

Ethyl 4-[5-methyl-2-(6-methyl-3-pyridyloxy)hexyloxy]benzoate (7). Yield 32\%; oil; ${ }^{1} \mathrm{H}-\mathrm{NMR} \delta\left(\mathrm{CDCl}_{3}\right): 0.89(3 \mathrm{H}$, $\left.\mathrm{t}, J=6.4 \mathrm{~Hz}, \mathrm{CH}_{3}\right), 0.91\left(3 \mathrm{H}, \mathrm{t}, J=6.4 \mathrm{~Hz}, \mathrm{CH}_{3}\right), 1.24-1.45$ $\left(2 \mathrm{H}, \mathrm{m}, \mathrm{CH}_{2}\right), 1.38\left(3 \mathrm{H}, \mathrm{t}, J=7.3 \mathrm{~Hz}, \mathrm{CH}_{3}\right), 1.53-1.62(1 \mathrm{H}$, $\mathrm{m}, \mathrm{CH}), 1.75-1.84\left(2 \mathrm{H}, \mathrm{m}, \mathrm{CH}_{2}\right), 2.50\left(3 \mathrm{H}, \mathrm{s}, \mathrm{CH}_{3}\right)$, 4.10-4.19 (2H, m, $\left.\mathrm{CH}_{2}\right), 4.34\left(2 \mathrm{H}, \mathrm{q}, J=7.3 \mathrm{~Hz}, \mathrm{CH}_{2}\right)$, 
4.51-4.56 (1H, m, CH), 6.89 (2H, d, J=8.8 Hz, phenyl), 7.06 $(1 \mathrm{H}, \mathrm{d}, J=8.3 \mathrm{~Hz}$, pyridyl), $7.19(1 \mathrm{H}, \mathrm{dd}, J=2.9,8.3 \mathrm{~Hz}$, pyridyl), $7.98(2 \mathrm{H}, \mathrm{d}, J=8.8 \mathrm{~Hz}$, phenyl), $8.26(1 \mathrm{H}, \mathrm{d}$, $J=2.9 \mathrm{~Hz}$, pyridyl).

Ethyl 4-[2-(6-methyl-3-pyridyloxy)octyloxy]benzoate (8). Yield 58\%; oil; ${ }^{1} \mathrm{H}-\mathrm{NMR} \delta\left(\mathrm{CDCl}_{3}\right): 0.88(3 \mathrm{H}, \mathrm{t}, J=6.8 \mathrm{~Hz}$, $\left.\mathrm{CH}_{3}\right), 1.25-1.54\left(8 \mathrm{H}, \mathrm{m}, 4 \mathrm{CH}_{2}\right), 1.38\left(3 \mathrm{H}, \mathrm{t}, J=7.3 \mathrm{~Hz}, \mathrm{CH}_{3}\right)$, 1.78-1.84 (2H, m, $\left.\mathrm{CH}_{2}\right), 2.50\left(3 \mathrm{H}, \mathrm{s}, \mathrm{CH}_{3}\right), 4.09-4.20(2 \mathrm{H}$, $\left.\mathrm{m}, \mathrm{CH}_{2}\right), 4.34\left(2 \mathrm{H}, \mathrm{q}, J=7.3 \mathrm{~Hz}, \mathrm{CH}_{2}\right), 4.54-4.58(1 \mathrm{H}, \mathrm{m}$, $\mathrm{CH}), 6.89(2 \mathrm{H}, \mathrm{d}, J=8.8 \mathrm{~Hz}$, phenyl), $7.06(1 \mathrm{H}, \mathrm{d}, J=8.3 \mathrm{~Hz}$, pyridyl), $7.20(1 \mathrm{H}, \mathrm{dd}, J=2.9,8.3 \mathrm{~Hz}$, pyridyl $), 7.98(2 \mathrm{H}, \mathrm{d}$, $J=8.8 \mathrm{~Hz}$, phenyl), 8.26 (1H, d, $J=2.9 \mathrm{~Hz}$, pyridyl).

Ethyl 4-[2-(6-methyl-3-pyridyloxy)decyloxy]benzoate (9). Yield 38\%; oil; ${ }^{1} \mathrm{H}-\mathrm{NMR} \delta\left(\mathrm{CDCl}_{3}\right): 0.87(3 \mathrm{H}, \mathrm{t}, J=6.8 \mathrm{~Hz}$, $\left.\mathrm{CH}_{3}\right), 1.24-1.54\left(12 \mathrm{H}, \mathrm{m}, 6 \mathrm{CH}_{2}\right), 1.38(3 \mathrm{H}, \mathrm{t}, J=7.3 \mathrm{~Hz}$, $\left.\mathrm{CH}_{3}\right), 1.76-1.84\left(2 \mathrm{H}, \mathrm{m}, \mathrm{CH}_{2}\right), 2.50\left(3 \mathrm{H}, \mathrm{s}, \mathrm{CH}_{3}\right), 4.09-4.20$ $\left(2 \mathrm{H}, \mathrm{m}, \mathrm{CH}_{2}\right), 4.34\left(2 \mathrm{H}, \mathrm{q}, J=7.3 \mathrm{~Hz}, \mathrm{CH}_{2}\right), 4.54-4.58(1 \mathrm{H}$, m, CH), $6.89(2 \mathrm{H}, \mathrm{d}, J=8.8 \mathrm{~Hz}$, phenyl), $7.06(1 \mathrm{H}, \mathrm{d}, J=8.3$ $\mathrm{Hz}$, pyridyl), $7.19(1 \mathrm{H}, \mathrm{dd}, J=2.9,8.3 \mathrm{~Hz}$, pyridyl), $7.98(2 \mathrm{H}$, $\mathrm{d}, J=8.8 \mathrm{~Hz}$, phenyl), $8.26(1 \mathrm{H}, \mathrm{d}, J=2.9 \mathrm{~Hz}$, pyridyl).

2.4. Ethyl 4-[(R)-4-methyl-2-(6-methyl-3-pyridyloxy)pentyloxy] benzoate (5R).

A solution of $0.46 \mathrm{~g}$ of methyl $(S)$-2-hydroxy-4-methylpentanoate, $0.60 \mathrm{~g}$ of $p$-toluenesulfonyl chloride and $0.38 \mathrm{~g}$ of triethylamine in $15 \mathrm{ml}$ of THF was stirred for $12 \mathrm{hr}$ at room temperature. To the mixture was added $30 \mathrm{ml}$ of ethyl acetate and the organic layer was washed with water and brine, dried over $\mathrm{Na}_{2} \mathrm{SO}_{4}$, and concentrated. The residue was purified by column chromatography on silica gel by eluting with hexaneethyl acetate $(3: 1)$ to afford $0.58 \mathrm{~g}(61 \%)$ of methyl $(S)-4$ methyl-2-p-toluenesulfonyloxypentanoate (III) as an oil. A mixture of $0.67 \mathrm{~g}$ of (III), $0.24 \mathrm{~g}$ of 5-hydroxy-2-methylpyridine and $0.31 \mathrm{~g}$ of potassium carbonate in $10 \mathrm{ml}$ of DMF was stirred for $12 \mathrm{hr}$ at room temperature. The product was extracted with $30 \mathrm{ml}$ of ethyl acetate. The organic layer was washed with water and brine, dried over $\mathrm{Na}_{2} \mathrm{SO}_{4}$, and concentrated. The residue was purified by column chromatography on silica gel by eluting with hexane-ethyl acetate $(5: 4)$ to give $0.44 \mathrm{~g}(83 \%)$ of methyl $(R)$-4-methyl-2-(6-methyl-3pyridyloxy)pentanoate (IV) as an oil. A mixture of $0.41 \mathrm{~g}$ of (IV) and $0.07 \mathrm{~g}$ of sodium borohydride in $10 \mathrm{ml}$ of ethanol was stirred for $24 \mathrm{hr}$ at room temperature. After removal of the solvent under reduced pressure, the product was extracted with ethyl acetate. The ethyl acetate solution was washed with water and brine, dried over $\mathrm{Na}_{2} \mathrm{SO}_{4}$, and concentrated. The residue, $(R)$-4-methyl-2-(6-methyl-3-pyridyloxy)pentanol, was converted to $(R)$-4-methyl-2-(6-methyl-3-pyridyloxy)pentyl $p$ toluenesulfonate $(\mathbf{V})$ by a reaction with $p$-toluenesulfonyl chloride in the same way as described in (II). Compound (V) was treated with ethyl 4-hydroxybenzoate in the same manner as that used for $\mathbf{5}$ to afford $\mathbf{5 R}$.

Compound 5R: $\mathrm{mp} 33-34^{\circ} \mathrm{C},[\alpha]_{\mathrm{D}}^{19}+37^{\circ}$ (c 1, ethanol). The enantiomeric purity was $82 \%$ ee by HPLC analysis under the following conditions: Column; CHIRALPAC AD-H
(4.6×250 mm, Daicel Chemical Industry Co.), Mobile phase; hexane-2-propanol (98:2), Detection; UV $260 \mathrm{~nm}$, Flow rate; $1 \mathrm{ml} / \mathrm{min}$

Compound $\mathbf{5 S}$ was prepared in the same manner as $\mathbf{5 R}$ with use of methyl $(R)$-2-hydroxy-4-methylpentanoate instead of the $(S)$-isomer.

Compound 5S: mp $38-39^{\circ} \mathrm{C},[\alpha]_{\mathrm{D}}^{19}-41^{\circ}$ (c 1, ethanol), Enantiomeric purity; $83 \%$ ee. The ${ }^{1} \mathrm{H}-\mathrm{NMR}$ spectra of $\mathbf{5 R}$ and $\mathbf{5 S}$ were entirely consistent with the spectrum of $\mathbf{5}$.

\subsection{4-[2-(6-Methyl-3-pyridyloxy)hexyloxy]benzoic} acid (4-acid).

A mixture of $0.91 \mathrm{~g}$ of 4 and $0.42 \mathrm{~g}$ of $\mathrm{NaOH}$ in $10 \mathrm{ml}$ of ethanol and $5 \mathrm{ml}$ of water was stirred for $24 \mathrm{hr}$ at room temperature. After removal of the solvent, the residue was dissolved in water. The aqueous solution was washed with ethyl acetate, and acidified with dil. $\mathrm{HCl}$. The product was extracted with ethyl acetate and the ethyl acetate solution was washed with brine, and dried over $\mathrm{Na}_{2} \mathrm{SO}_{4}$. Concentration of the ethyl acetate solution afforded $0.42 \mathrm{~g}(48 \%)$ of 4-acid as a solid, mp $125-127^{\circ} \mathrm{C} .{ }^{1} \mathrm{H}-\mathrm{NMR} \delta\left(\mathrm{CDCl}_{3}\right): 0.93(3 \mathrm{H}, \mathrm{d}$, $\left.J=7.3 \mathrm{~Hz}, \mathrm{CH}_{3}\right), 1.34-1.53\left(4 \mathrm{H}, \mathrm{m}, 2 \mathrm{CH}_{2}\right), 1.78-1.85(2 \mathrm{H}, \mathrm{m}$, $\left.\mathrm{CH}_{2}\right), 2.54\left(3 \mathrm{H}, \mathrm{s}, \mathrm{CH}_{3}\right), 4.12-4.23\left(2 \mathrm{H}, \mathrm{m}, \mathrm{CH}_{2}\right), 4.58-4.62$ $(1 \mathrm{H}, \mathrm{m}, \mathrm{CH}), 6.92(2 \mathrm{H}, \mathrm{d}, J=8.8 \mathrm{~Hz}$, phenyl), $7.10(1 \mathrm{H}, \mathrm{d}$, $J=8.3 \mathrm{~Hz}$, pyridyl), $7.24(1 \mathrm{H}, \mathrm{dd}, J=2.9,8.3 \mathrm{~Hz}$, pyridyl), $8.03(2 \mathrm{H}, \mathrm{d}, J=8.8 \mathrm{~Hz}$, phenyl), $8.32(1 \mathrm{H}, \mathrm{d}, J=2.9 \mathrm{~Hz}$, pyridyl).

\section{Biological Evaluation}

B. mori (Shunrei $\times$ Shougetsu) larvae were reared on an artificial diet as previously reported. ${ }^{9)}$ Test compounds in acetone solution were applied topically to $24 \mathrm{hr}$-old $3 \mathrm{rd}$ instar and newly molted 4th instar larvae. Compounds 4 and 4-acid were mixed with the artificial diet at concentrations of 50 and 200 ppm according to the procedure reported. ${ }^{10)}$ The diet containing a test compound was administered throughout the 3rd larval period. Twenty larvae were used for each dose. The activity of compounds was evaluated by the induction of precocious metamorphosis: spinning a cocoon and subsequent pupation or formation of larval-pupal intermediates from the 4 th instar (penultimate) larval period.

\section{Western Blot Analysis of JHE and JHE Activity Assay} Compound 5 ( $100 \mu \mathrm{g} /$ larva) was topically applied to $24 \mathrm{hr}$-old 3 rd instar larvae, and hemolymph was collected from newly molted 4th instar larvae at $24 \mathrm{hr}$ intervals and stored at $-80^{\circ} \mathrm{C}$ until used. Western blot analysis of JHE in the hemolymph was performed by separating the proteins with a $10 \%$ SDSPAGE gel and then transferring them onto a PVDF membrane. The JHE protein on the membrane was probed with antibodies to JHE and positive reactions were detected with a goat anti-rabbit IgG antibody conjugated with alkaline phosphatase. ${ }^{11)}$ JHE activity was determined by a spectrophotometric assay using $S$-methyl heptylthioethanethioate (HTET) as a $\mathrm{JH}$ mimic substrate. ${ }^{11)}$ The assay was done in $0.05 \mathrm{M}$ 
(A)
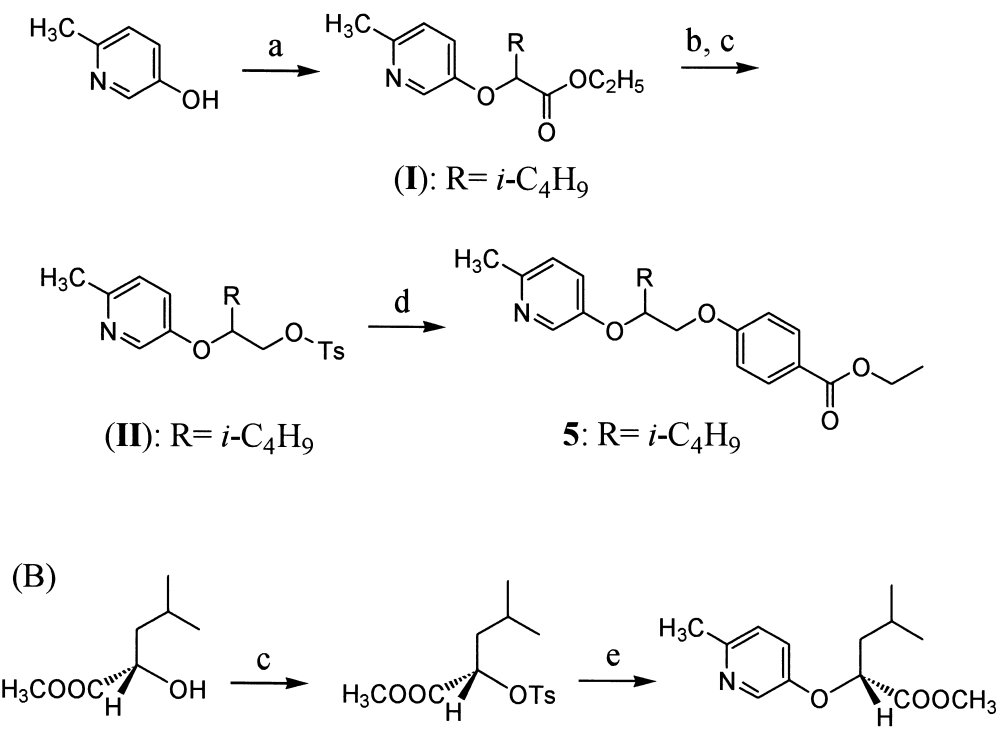

(III)

(IV)

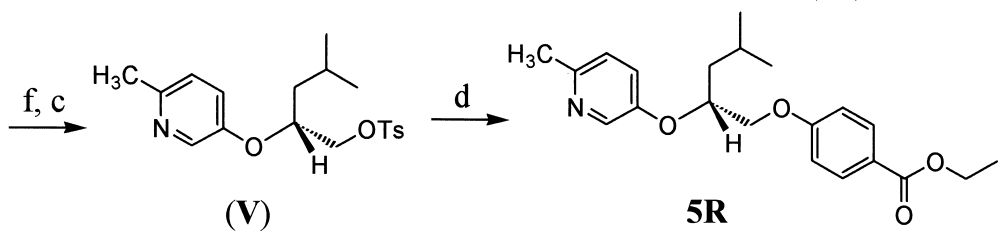

Fig. 1. Scheme for the preparation of (A) ethyl 4-[2-(6-methyl-3-pyridyloxy)alkyloxy]benzoates and (B) ethyl 4-[(R)-4-methyl-2-(6-methyl-3pyridyloxy)pentyloxy]benzoate (5R). (a) ethyl 2-bromoalkanoate, $\mathrm{K}_{2} \mathrm{CO}_{3}$, DMF; (b) $\mathrm{LiAlH}_{4}$, THF; (c) p-toluenesulfonyl chloride, triethylamine, THF; (d) ethyl 4-hydroxybenzoate, $\mathrm{K}_{2} \mathrm{CO}_{3}$, DMF; (e) 5-hydroxy-2-methylpyridine, $\mathrm{K}_{2} \mathrm{CO}_{3}$, DMF; (f) $\mathrm{NaBH}_{4}$, ethanol.

sodium phosphate ( $\mathrm{pH} 7.4$ ) containing $10 \%$ sucrose. The buffer $(293 \mu \mathrm{l})$ supplemented with $0.025 \%$ of 3-carboxy-4-nitrophenyl disulfide was preincubated at $25^{\circ} \mathrm{C}$ for $5 \mathrm{~min}$. Two microliters of substrate solution $(30 \mathrm{mM}$ HTET in ethanol) and $5 \mu \mathrm{l}$ of hemolymph were then added to the buffer and absorbance at $405 \mathrm{~nm}$ was recorded for $2 \mathrm{~min}$ on a microplate reader.

\section{RESULTS AND DISCUSSION}

Table 1 shows the precocious metamorphosis-inducing activity of ethyl 4-[2-(6-methyl-3-pyridyloxy)alkyloxy]benzoates and ETB in $24 \mathrm{hr}$-old 3rd instar and newly molted 4th instar larvae of $B$. mori. ETB at $1 \mu \mathrm{g}$ showed some activity when applied to 3rd-instar larvae, but at high doses of 10 and $40 \mu \mathrm{g}$ the activity disappeared, consistent with a report that ETB did not exhibit any anti-JH activity at high doses. ${ }^{7)}$ In contrast to ETB, compound $\mathbf{1}$ induced precocious metamorphosis at a rather high dose. The introduction of a propyl (2) and isopropyl (3) group gave analogs with almost the same level of activity as $\mathbf{1}$, while the $n$-butyl analog 4 was more active than $\mathbf{1}$, inducing precocious metamorphosis at both low and high doses when applied to $3 \mathrm{rd}$ instar larvae. The isobutyl analog 5 had somewhat stronger activity than 4 . The activity of the tert-butyl (6), isopentyl (7) and $n$-hexyl (8) analogs was found to decrease in comparison with that of 5. Interestingly, the $n$ octyl analog 9 as well as the ethyl analog 1 showed some activity. Thus, the isobutyl analog $\mathbf{5}$ was the most active of the compounds tested on 3rd instar larvae, however, it could not cause $100 \%$ precocious pupation even at higher doses (data not shown).

Horn et al. have synthesized both enantiomers of ETB and found that the anti-JH activity at low dose levels and JH activity at higher levels in $M$. sexta larvae were entirely due to the $(S)$ - $(-)$-enantiomer, the $(R)-(+)$-isomer being completely inactive. ${ }^{12)}$ We therefore prepared both the enantiomers of 5 by starting with L- and D-leucine, and determined the enantiomeric purities of $\mathbf{5 R}(+)(82 \%$ ee) and $\mathbf{5 S}(-)(83 \%$ ee) by chiral HPLC. In contrast to the results obtained with ETB, there was no significant difference in precocious metamorphosis-inducing activity between the $\mathbf{5 R}(+)$ - and $\mathbf{5 S}(-)$-enatiomers.

When 24 hr-old 3rd instar larvae were treated with ETB or a series of ethyl alkyloxybenzoates, precocious metamorphosis always occurred at the 4th larval stage. ETB did not induce precocious metamorphosis when applied to newly molted 4th instar larvae, similar to the results reported by Kiguchi et al. ${ }^{4)}$ We found that compounds 3 and 5-8 showed weak precocious metamorphosis-inducing activity when 
Table 1. Precocious metamorphosis-inducing activity of ethyl 4-[2-(6-methyl-3-pyridyloxy)alkyloxy]benzoates and ETB against 3rd and 4th instar larvae of B. mori

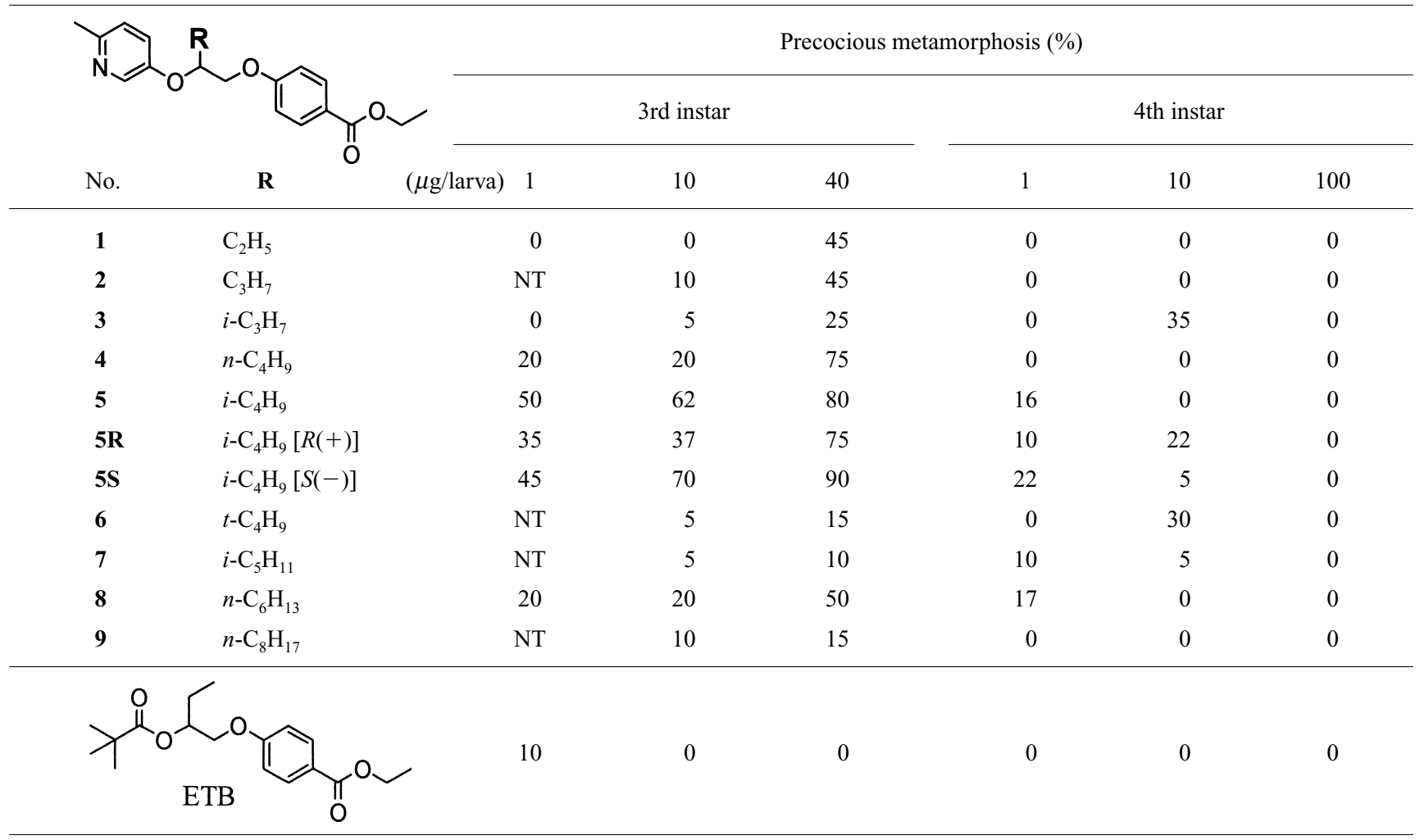

Values are the average of two experiments. The compounds described in this table are racemic unless otherwise specified. NT: not tested.

tested on newly molted 4th instar larvae. However, their activity did not correlate with the doses applied; some activity appeared at low dose levels, but at a dose of $100 \mu \mathrm{g}$, no activity was observed. It is interesting that all compounds with a branched alkyl chain except 8 were active against 4th instar larvae. It remains to be seen whether or not these active compounds as well as ETB have JH-like activity.

We have previously reported that a number of 3-pyridine derivatives $^{9)}$ and 1,5-disubstituted imidazoles ${ }^{10)}$ induced precocious metamorphosis in B. mori larvae by causing a temporary decline in ecdysteroid titers in the larval hemolymph, because their activity was completely reversible by the dietary administration of 20-hydroxyecdysone. We examined the effects of methoprene, a $\mathrm{JH}$ agonist, and 20-hydroxyecdysone on precocious metamorphosis induced by $\mathbf{5}$ (Table 2 ). The activity of $\mathbf{5}$ to induce precocious pupation was completely counteracted by the simultaneous application of methoprene to $24 \mathrm{hr}$-old 3rd instar larvae or methoprene applied immediately after the 3rd ecdysis, but not by the dietary administration of 20-hydroxyecdysone, similar to the results obtained for 1. $^{7)}$ The results of the rescue experiments indicate that 5 induces precocious metamorphosis in $B$. mori larvae by causing a deficiency of JH titers in the larval hemolymph.

In our previous study, the 4-ethoxycarbonyl group of $\mathbf{1}$ was found to be significant for activity. ${ }^{7)}$ Since ethyl alkyloxyben-
Table 2. Effects of methoprene and 20-hydroxyecdysone on precocious metamorphosis induced by compound $\mathbf{5}$ in $B$. mori larvae

\begin{tabular}{|c|c|c|}
\hline Compound & $\begin{array}{c}\text { Time of } \\
\text { treatment } \\
\text { (larval instar) }\end{array}$ & $\begin{array}{c}\text { Precocious } \\
\text { metamorphosis } \\
(\%)\end{array}$ \\
\hline 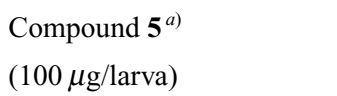 & $3 \mathrm{rd}$ & 85 \\
\hline $\begin{array}{r}+ \text { Methoprene }^{b)} \\
\quad(10 \mu \mathrm{g} / \text { larva })\end{array}$ & $3 \mathrm{rd}$ & 0 \\
\hline $\begin{array}{l}\text { + Methoprene } \\
\text { (10 } \mu \mathrm{g} / \text { larva })\end{array}$ & 4 th & 0 \\
\hline $\begin{array}{l}+20 \text {-Hydroxyecdysone }{ }^{c)} \\
(20 \mathrm{ppm})\end{array}$ & $3 \mathrm{rd}$ & 80 \\
\hline $\begin{array}{l}+20 \text {-Hydroxyecdysone } \\
\text { (20 ppm) }\end{array}$ & 4 th & 75 \\
\hline
\end{tabular}

a) Compound 5 was applied to $24 \mathrm{hr}$-old $3 \mathrm{rd}$ instar larvae.

${ }^{b)}$ Methoprene was topically applied to $24 \mathrm{hr}$-old $3 \mathrm{rd}$ or newly molted 4th instar larvae.

${ }^{c}$ The diet containing 20-hydroxyecdysone was administered for the first $48 \mathrm{hr}$ to $24 \mathrm{hr}$-old $3 \mathrm{rd}$ or newly molted 4 th instar larvae. 
Table 3. Precocious metamorphosis-inducing activity of compounds $\mathbf{4}$ and $\mathbf{4 - a c i d}$ on dietary administration in 3rd instar larvae of B. mori

\begin{tabular}{ccc}
\hline Compound & $\begin{array}{c}\text { Concentration } \\
(\mathrm{ppm})\end{array}$ & $\begin{array}{c}\text { Precocious } \\
\text { metamorphosis } \\
(\%)\end{array}$ \\
\hline & 50 & 65 \\
& 200 & 65 \\
\end{tabular}

The diets containing compounds $\mathbf{4}$ and $\mathbf{4}$-acid were administered throughout the 3rd larval period.

zoates might be hydrolyzed to the corresponding alkyloxybenzoic acids in the larval hemolymph, we examined the activity of 4-[2-(6-methyl-3-pyridyloxy)hexyloxy]benzoic acid (4-acid), which was relatively easy to prepare. Compound 4acid did not show any activity on topical application at a wide range of doses (1-100 $\mu \mathrm{g}$ ), presumably due to decreased penetration through the larval cuticle. Therefore, its activity was examined on dietary administration (Table 3). Compound 4 induced precocious metamorphosis on dietary administration as well as topical application, while compound 4-acid showed no activity at concentrations of 50 and $200 \mathrm{ppm}$, suggesting that in this series of compounds, the ethoxycarbonyl group itself is responsible for the activity.

$\mathrm{JH}$ esterase (JHE), which hydrolyzes the methyl ester of $\mathrm{JH}$ into inactive $\mathrm{JH}$ acid, has an important role as one of the major factors involved in the regulation of $\mathrm{JH}$ during the last instar. ${ }^{13)}$ In the silkworm, JHE activity in the hemolymph is quite low during the 4 th instar and increases at the 5th instar, thereby decreasing the $\mathrm{JH}$ titer and inducing metamorphosis. ${ }^{14)}$ Shiotsuki et al. have found that KK-42, the most effective inducer of precocious metamorphosis in the silkworm, enhances JHE activity in the hemolymph of the 4th instar larvae and subsequently causes precocious pupation, and have suggested that the appearance of JHE activity in the he-

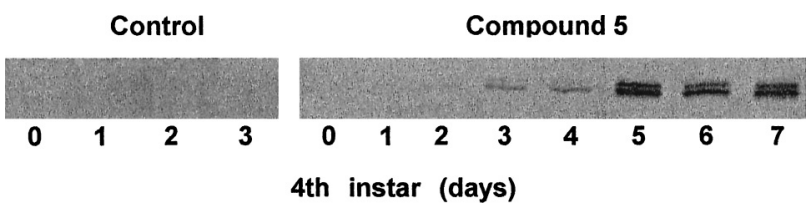

Fig. 2. Western blot analysis of JHE protein in hemolymph. Compound 5 (100 $\mu \mathrm{g} /$ larva) was topically applied to $24 \mathrm{hr}$-old $3 \mathrm{rd}$ instar larvae. Hemolymph was collected daily from 4th instar control larvae and compound 5-treated larvae, and separated on 10\% SDS-PAGE gel. The number under each lane indicates the day of 4th instar larvae.

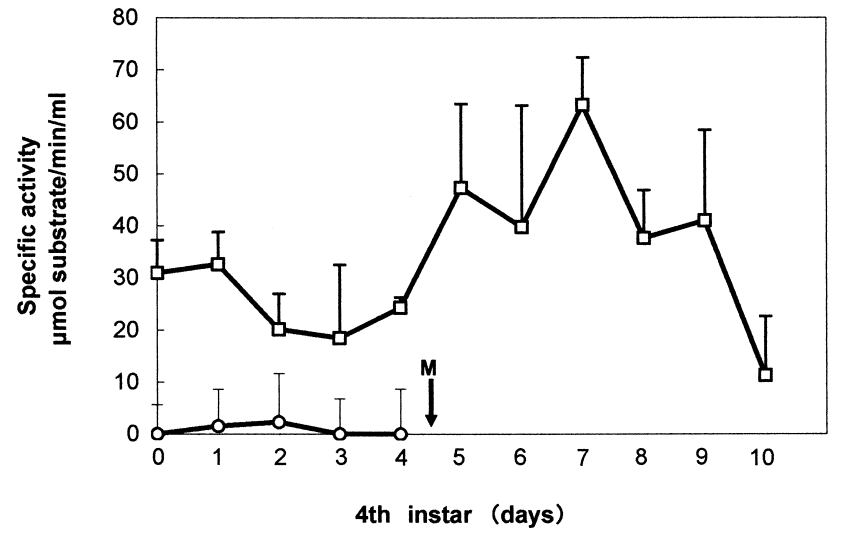

Fig. 3. Hemolymph JHE activity during the 4th instar. Acetonetreated control larvae $(\bigcirc)$; compound 5-treated larvae $(\square)$. Compound 5 (100 $\mu \mathrm{g} /$ larva) was topically applied to $24 \mathrm{hr}$-old $3 \mathrm{rd}$ instar larvae. $\mathrm{M}$ indicates the 4 th ecdysis in the control. Each value represents the mean of four determinations with the standard deviation.

molymph is a key factor for metamorphosis. ${ }^{14)}$ We examined whether hemolymph JHE was expressed in the 4th instar larvae destined to undergo precocious metamorphosis on treatment with 5. The amount of JHE protein in the hemolymph was determined by Western blot analysis (Fig. 2) and JHE activity was monitored by using a spectrophotometric assay (Fig. 3). ${ }^{11)}$ In the 4 th instar larvae of the acetone-treated control, JHE protein was not detected and no increase in hemolymph JHE activity was observed. When compound 5 was applied to the 3rd instar larvae, JHE protein was clearly detected from days 3 to 7 in the 4 th instar larvae. Although in early 4th instar larvae JHE protein was not observed, hemolymph JHE activity appeared immediately after the ecdysis to the 4th instar larvae. The reason for this difference is unknown. However, the pattern of hemolymph JHE activity, which increased gradually from day 3 in the 4th instar larvae, correlated with the distribution of hemolymph JHE protein. The JHE activity observed in compound 5-treated larvae was similar to that in the control 5th instar larvae and in KK42treated larvae. ${ }^{14)}$ This result supports the concept that the appearance of JHE activity in the hemolymph is indispensable for the initiation of pupation.

In conclusion, compound $\mathbf{5}$ represents a structurally novel class of potent anti-JH agent that induces precocious metamorphosis and JHE activity in the 4th instar (penultimate) larvae of B. mori. Other biological activities and the mode of action of this series of compounds are under investigation.

\section{ACKNOWLEDGMENTS}

We thank Ms. Yuko Sakaki for her technical support. This work was supported by a grant-in-aid to E.K. for scientific research (no. 14360031) from the Ministry of Education, Culture, Sports, Science, and Technology of Japan. 


\section{REFERENCES}

1) G. B. Staal: Annu. Rev. Entomol. 31, 391-429 (1986).

2) M. Castillo, P. Moya, F. Couillaud, M. D. Garcera and R. Martinez-Pardo: Arch. Insect Biochem. Physiol. 37, 287-294 (1998).

3) G. B. Staal: Entomol. Exp. Appl. 31, 15-23 (1982).

4) K. Kiguchi, T. Mori and H. Akai: J. Insect Physiol. 30, 499-506 (1984).

5) J. P. Edwards, B. J. Bergot and G. B. Staal: J. Insect Physiol. 29, 83-89 (1983).

6) L. M. Riddiford, C. R. Roseland, S. Thalberg and A. T. Curtis: $J$. Insect Physiol. 29, 281-286 (1983).

7) H. Ishiguro, N. Fujita, I.-H. Kim, T. Shiotsuki and E. Kuwano: Biosci. Biotechnol. Biochem. 67, 2045-2047 (2003).

8) N. Valls, M. Vallribera, M. Lopez-Canet and J. Bonjoch: J. Org.
Chem. 67, 4945-4950 (2002).

9) T. Yoshida, T. Shiotsuki and E. Kuwano: J. Pestic. Sci. 25, 253-258 (2000).

10) E. Kuwano, T. Hisano, M. Sonoda and M. Eto: Biosci. Biotechnol. Biochem. 58, 1309-1310 (1994).

11) M. Hirai, M. Kamimura, K. Kikuch, Y. Yasukochi, M. Kiuchi, T. Shinoda and T. Shiotsuki: Insect Biochem. Mol. Biol. 32, $627-635$ (2002).

12) D. H. S. Horn, R. H. Nearn, J. B. Siddall, G. B. Staal and D. C. Cerf: Aust. J. Chem. 36, 1409-1417 (1983).

13) T. C. Sparks, B. D. Hammock and L. M. Riddiford: Insect Biochem. 13, 529-541 (1983).

14) T. Shiotsuki, F. Yukuhiro, M. Kiuchi and E. Kuwano: J. Insect Physiol. 45, 1049-1055 (1999). 